\title{
Analysis of Factors Impacting on Farmer's Response to the Grain for Green Project----Base on the Investigation of 154 Households in Yunnan Province
}

\author{
Shui-Fa KE ${ }^{1, a,{ }^{*}}$, Qiang SHEN ${ }^{2, b}$, Tie-Zhen $\mathrm{ZHAO}^{3, \mathrm{c}}$ \\ ${ }^{1}$ School of Agricultural Economics and Rural Development, Renmin University of China, Beijing, \\ 100872, China \\ ${ }^{2}$ College of Economics and Management, Beijing Forestry University, Beijing 100083, China \\ 3Journal of Forestry Economics, China National Forestry Economics and Development Research \\ Center, Beijing 100102, China \\ akeshuifa@163.com, brunkite@gmail.com, ctiezhenzhao@163.com \\ ${ }^{*}$ Corresponding author
}

Keywords: Land use, The Grain for Green Project, Farmer household, Factors, Yunnan province.

\begin{abstract}
Based on the investigation of 154 households in Xinping county, Huize county, Simao district in Yunnan province, Binary Logistic regression Analysis has been used to analyze the influence factors of farmer's willingness to participate in this program in the later era of Grain for Green Project. The results shown that the farmer has a good understanding of the purpose and the compensation of this policy; culture level, cultivated land area, participation of the program or not, satisfied with compensation or not, the policy is important or not, satisfied with the implementation of the village cadre will affect farmer's willingness of participation in the later era of GGP. Some suggestions were put forward as follows: continue to strengthen policy propaganda and project management, strengthen the compensation management; also, promote the migration of rural surplus labor.
\end{abstract}

\section{Introduction}

In order to improve the ecological environment in the western region of China, reduce the harm to environment from slope farmland and land which is easy to cause desertification, China launched the Grain for Green Project in Shanxi, Sichuan and Gansu first in 1999, until now, 25 provinces (district, city) and Xinjiang Production and Construction Corps have participated in the project. The State Council, taking into account the necessarily requirement of 18 million mu of arable land in store, has kept this project into a consolidation phase from 2007.Yunnan province started the pilot work of Grain for Green Project in 2000-2001, then comprehensively promote this project in the province from 2002. As of 2012, the implementation area in Yunnan covers 17.3 millions of land, 129 counties, 1.3 millions of households and 5.5 millions of people. Also, they are launching a comprehensive implementation of the Grain for Green Project in Kunming from 2012, while continue to consolidate national achievements on the basis of Grain for Green Project, the goal of the Grain for Green Project in Kunming is to convert 1.71 acres of land to forest in 10 years.

The Grain for Green Project has been implemented for 10 years, among the six key forestry projects; it has the closest interests with farmers. So, having a good knowledge of farmer's understanding of the project, willingness to participate is important for the implementation in late era of GGP. According to Xie Shungyu etc, before you response towards any policy, firstly you should know and understand it, then, you should support it, at last, you can act to response towards the policy[1]. Until now, some scholars already have carried out some related researches, which provide useful references for this study [2-5]. This paper concerns the farmer's understanding of GGP, willingness to participate, the problems of the implementation of the GGP and farmer's 
expectation after 10 years of implementation of GGP in Yunnan province, this study provides decision-making references for the implementation of GGP in the western region of China.

\section{Sample area, data sources, model selection and index design}

\section{Sample area}

In order to select reasonable sample counties, we take into account county location, economic conditions, natural resource conditions and the implementation of GGP etc. at the end, we pick Xinping county, Huize county, Simao district in Yunnan province.

Xinping county is located between $23^{\circ} 38^{\prime} 15^{\prime \prime} \sim 24^{\circ} 26^{\prime} 05^{\prime \prime} \mathrm{N}$ and $101^{\circ} 16^{\prime} 30^{\prime \prime} \sim 102^{\circ} 16^{\prime} 50^{\prime \prime} \mathrm{E}$, which is surrounded by mountains and rivers, and has abundant forest resources. Its geographical location, climate, soil etc are good for forestry, which provides good growing conditions for the trees that planted in the Grain for Green Project. Huize county is located in the northeast of Yunnan Province, Jinsha east coast, northwest of Qujing City, between $103^{\circ} 03^{\prime} \sim 103^{\circ} 55^{\prime} \mathrm{N}$ and $25^{\circ} 48^{\prime} \sim 27^{\circ} 04^{\prime} \mathrm{E}$. Huize has a typical temperate monsoon climate, the annual average temperature is $12.6^{\circ} \mathrm{C}$ and the average annual rainfall is $817.7 \mathrm{~mm}$. Simao district is located in southern of Yunnan Province, south central of Pu'er City, between $22^{\circ} 27^{\prime} \sim 23^{\circ} 06^{\prime} \mathrm{N}$ and $100^{\circ} 19^{\prime} \sim 101^{\circ} 27^{\prime} \mathrm{E}$. It is the center of city's political, economic, and cultural and transportation hub which is connecting Southeast Asia. Its annual average temperature is $17.9^{\circ} \mathrm{C}$ and the average annual rainfall is 1517.8 $\mathrm{mm}$. This district is in the key forest zone in Yunnan province, which has 456 acres of woodland and the forest coverage rate is 76.9 percent.

\section{Data sources}

The data used in this study mainly from the field research, also some from relevant statistical document. The field research is conducted through informal interviews with local households to understand the actual situation. The research team conducts this investigation in Yunnan in August 2012, we conducted the typical sample survey in Xinping county, Huize county, Simao district, in the end, and we received 154 valid questionnaires.

\section{Model selection}

In the study of farmer's willingness to participate in the late area of GGP, we will choose Binary logistic regression analysis. Whether Farmers are willing to participate or not can be defined as a binary decision. $\mathrm{Y}=1$ represents farmers are willing to participate, $\mathrm{Y}=0$ represents farmers are not willing to participate. In order to find the relation between impact factor X1, X2 ... Xn and farmers` willingness to participate, we establish the regression model:

$$
\mathrm{P}=\mathrm{P}(Y=1)=\frac{\exp \left(\alpha+\beta_{1} X_{1}+\beta_{2} X_{2}+\ldots+\beta_{n} X_{n}\right)}{1+\exp \left(\alpha+\beta_{1} X_{1}+\beta_{2} X_{2}+\ldots+\beta_{n} X_{n}\right)}
$$

In the formula (1), $\alpha$ is a constant, $\beta_{1}, \beta_{2} \ldots \beta_{n}$ are the regression coefficient, they are on the behalf of how much will the impact factor influence $Y$.

\section{Index selection}

In this study, in order to analyze the impact factors of farmer's willingness to participate in the Grain for Green Project in the later era of GGP, we use some related domestic researches as references to know that key impact factors can be divided into the following six categories : (1) Characteristics of householders. Householders are the decision-makers and key players of production and business activities, their behavior will directly influence the sustainability of this project and determine the effect of the implementation of the project. However, the behavior of 
householders maybe effected by gender, age, education, awareness of this project, compensation expectation, feelings of environmental change, whether participate in this project now or not etc. (2) Characteristics of households' production and operation. This feature determines income level of farmers' household production; it plays a key role in participating in the policy sustainably. Resource endowments of production and management are the most important factors. Which includes the number of labor force, forest resources, land resources etc. (3) Characteristics of farmer household. it mainly includes the population of the Household, the number of elderly and young children, health status of family members etc. (4) Characteristics of the implementation by the local government. During the implementation of this project, the behavior of local government, especially Village cadres will affect farmers' willingness to participate. (5) Characteristics of village where farmers live in. Thanks to farmers live in the village as individuals, their behaviors are directly or indirectly affected by the characteristics of this village. The features include village location, the village's economic development status and other factors, distance between the county and the village will directly affect traffic, the way of receiving information, economic development and so on. (6) Characteristics of other external factors, in addition to the above characteristics, farmer's behavior may also be subject to growth of the market of agricultural and forestry products, market prices and other factors as well as other relevant policies and the status of grain for green in the neighborhood and other factors.

Based on the above characteristics analysis and field research situation, 14 key indicators were selected in this research, which are shown in Table 1.

Table 1 Basic information of variables

\begin{tabular}{cc}
\hline Variable & Variable Description \\
\hline Age & $1<40,2=40 \sim 50,3>50$ \\
Education & $\begin{array}{c}1=\text { illiteracy, } 2=\text { Primary school, } 3= \\
\text { junior high school, } 4>=\text { senior middle } \\
\text { school }\end{array}$ \\
Environmental Change & $\begin{array}{c}1=\text { worse, } 2=\text { no change, } 3=\text { better } \\
1=\text { no, } 2=\text { yes }\end{array}$ \\
Participate in GGP or not & $1=$ unsatisfied, $2=$ average, $3=$ satisfied \\
Satisfied with the compensation & $1=$ no, $2=$ average, $3=$ yes \\
or not & $1<5 \mathrm{mu}, 2=5 \sim 10 \mathrm{mu}, 3>10 \mathrm{mu}$ \\
GGP is important or not & $1<20 \mathrm{mu}, 2=20 \sim 50 \mathrm{mu}, 3>50 \mathrm{mu}$ \\
Arable land & $1<=1,2=2,3>=2$ \\
Forest land & $1<=1,2=2,3>=2$ \\
Labor force & $1=$ close, $2=$ average, $3=$ far \\
young and old & $1=$ low, $2=$ average, $3=$ high \\
village & $1=$ bad, $2=$ average, $3=$ good \\
Living standard & $1=$ Xinping, $2=$ Huize, $3=$ Simao
\end{tabular}

\section{Descriptive Analysis}

\section{The basic situation of the households surveyed}

Among the 154 investigated farmers, 122 farmers are the head of the household, which accounts for $79.22 \%$; 133 farmers are male, which accounts for $86.36 \%$; The youngest is 20 years old, the oldest is 68 years old, the average age is 43 years old, farmers investigated are mainly concentrated 
in the age of 40 to 50 . In terms of education, $4.5 \%$ are illiteracy, $44.2 \%$ only have elementary diploma,41.6\% only have junior high school diploma, 9.7\% have high school diploma or above. Most farmers only have elementary diploma or junior high school diploma, few of them have high school diploma or above, overall, it shows the area we have investigated has a low education level. Party member accounts for $30.52 \%$ among them; $27.27 \%$ have been village cadres; $8.78 \%$ ever specialize in forestry work. In terms of the nature resources, every household has four pieces of woodlands on average, which totally covers $37 \mathrm{mu}(1 \mathrm{hm} 2=15 \mathrm{mu})$; every household also has four pieces of farmland on average, which totally covers $8 \mathrm{mu}$.

\section{The farmer households' response to the GGP}

Most households believed that protection of the ecological environment is the primary goal of Grain for Green Project. When they were asked the purpose of the GGP, 83.12\% go to protection of the ecological environment, $38.31 \%$ go to the improving their living standards, $27.27 \%$ go to the promoting the development of forestry.

Over half of the households understand grain for green policy. When they were asked whether they understand this policy or not, about $70 \%$ of households understand this policy, among them, $14.29 \%$ think they know it very well, $31.82 \%$ think they have good understand , $29.22 \%$ think they understand the basic of this policy.

The main channel to understand this policy was going through village cadres' propaganda. Nowadays, farmers know policy through many channels, $82.47 \%$ of households know and understand this policy by the channel of propaganda brought by the village cadres, $41.56 \% \mathrm{know}$ it from TV news, $9.09 \%$ know it from newspaper, $4.55 \%$ know it from neighbors or relatives, $1.9 \%$ know it from internet, and $8.44 \%$ know it from other ways.

Over half of the respondents think that the ecological environment of the village has been improved. After 10 years of implementation of Grain for Green Project, 83.8\% of households think that the ecological environment of the village has been improved.11\% think that ecological environment has no change, even 5.2\% think that their ecological environment becomes worse.

According to the questionnaires, $97.8 \%$ of the households successfully completed the task, $71.8 \%$ of the households are satisfied with the overall implementation, however, some problems are shown during the implementation, the problem of Compensation standards is the most serious problem, nearly $40 \%$ of households think that the standards is too low, they think they can gain more if they just use the land to grow grain. The form of compensation includes cash and food subsidies. At first, households who participate can get $260 \mathrm{RMB}$ one mu, now they can only get half. We also find that if compensation stops, nearly $30 \%$ of the households will change the use of the land, the main reasons why the others who do not change are as follows: some areas, just like Simao, they plant economic forest at first, now some can benefit from it, also, some households 'main income are not from forest, due to the inertia or emphasis on ecological construction, they are willing to continue.

Aside from the problem of compensation standards, $21.43 \%$ of the households think the term of this project is too short; $18.82 \%$ of the households thinks this project has been less invested; $16.35 \%$ of the households think the allocation of index is not fair; $11.38 \%$ of the households think that the information of this project are not transparent; also, some think that the index are not enough etc. The above problems may affect farmers' enthusiasm to participate in the GGP.

\section{Result}

According to the investigation, we found that some farmers were forced to participate in this project. the result shows that $18.7 \%$ of the respondents were not voluntarily to participate. From the long-term perspective, going against famers' will is not good for the sustained implementation of the GGP, which also contributed to the fact that some people cut the trees in GGP zone secretly in 
some area we investigated. So, it is important for us to analyze farmers' willingness to participate in this project. Based on the indicators in Table 1, with the help of SPSS18.0, we used the data from 154 questionnaires for processing of binary logistic regression. During the processing, we use the way of backward condition, we test 14 factors in the model at first, then the factors not significant will be excluded, then we will test the rest factors in the model again, until the factors in the model will all be significant. After the processing, the final estimation results are shown in Table 2.

\section{Table 2 Result on Logistic model estimation of farmers' willingness on participation in GGP}

\begin{tabular}{cccccc}
\hline Variable & B & S.E & Wals & DF & Sig \\
\hline Constant & 14.839 & 3.75 & 15.656 & 1 & $0.001^{* * *}$ \\
Education & 1.074 & 0.467 & 5.291 & 1 & $0.021^{\text {** }}$ \\
Arable land & 1.043 & 0.459 & 5.157 & 1 & $0.023^{* *}$ \\
Participate in GGP or not & 1.612 & 0.716 & 5.066 & 1 & $0.024^{* *}$ \\
$\begin{array}{c}\text { Satisfied with the } \\
\text { compensation or not }\end{array}$ & 0.927 & 0.399 & 5.383 & 1 & $0.020^{* *}$ \\
$\begin{array}{c}\text { GGP is important or not } \\
\text { Service of Village cadres }\end{array}$ & 1.924 & 0.72 & 7.134 & 1 & $0.008^{* * *}$ \\
during the implementation & 1.091 & 0.427 & 6.531 & 1 & $0.011^{* *}$ \\
\hline
\end{tabular}

Note: $* * *$, and $* * *$ indicates a significant level of $10 \%, 5 \%, 1 \%$

In terms of the test of this regression analysis, the value of -2 Log likelihood is 86.3 , Nagelkerke $\mathrm{R}$ square is 0.45 , the final model works well and the regression results can be feasible.

The main factors influencing the farmers' willingness on participation are as follows: (1) the head of household who has high education level more willingness to participate the GGP than the low educational level. (2) The more arable land farmers have, they more willing to participate, the reason maybe that farmers can use the land as part of arable land to grow grain to eat, the excess land can be used in GGP, so they have time to do something else. (3)The farmers who have been participated more willing to participate than farmers have not been participated, maybe the former has benefited, their salary level has been improved or have more opportunity to work etc. (4) Farmers who are satisfied with compensation more willing to participate than those not, after all, from a rational perspective, farmers are pursuing their own maximized economic interests. (5) Those who recognize the importance of GGP more willing to participate than those does not. (6)Farmers who satisfied with the work by Village cadres during the implementation more willing to participate than those don't. The regression results also exist some shortcomings, for example, regional dummy variable fails the test, which seems impossible according to our findings in the field research, maybe, it is caused by fewer samples in Huize comparing with other two areas.

\section{Conclusions and Suggestions}

Some conclusions could be summarized as follows: (1) In general, farmer households have good response to support the GGP; (2) Benefit from the GGP is a key point for household volunteer to take part in the project; (3) Householder making a important decisions for the households' response;(4) Village leader groups play a key role in the implementation of GGP; (5) Household's response were impacted by a series of factors. (6) Compensation policy is an important factor for impacting the household's response.

Some suggestions were put forward as follows: (1) The forest sector should strengthen policy propaganda and project management to raise the environmental awareness of local households, and let households know well about the project policy; (2)continue to perfect the compensation policy, if farmers opportunity cost of re-cultivation are higher than compensation, the government can appropriately extend the subsidy period. According to the current cost of the project, the government can adopt a flexible approach, choose the economical way to compensate and how 
much to compensate [6];(3) promote the migration of rural surplus labor; The local government should provide technically training about the GGP for farmers, on the other hand, they should also improve their working skills and technical levels, so they can find suitable jobs independently. In the meantime, the local government could increase the export of organized labor services, which will increase revenue for farmers and provide a new way for famers to live their own life.

\section{Acknowledgement}

This research was financially supported by the National Social Science Fund Project (Project No. 13BJY060)

\section{References}

[1] XIE Shuangyu, YANG Yi, PAN Ling etc. A study on urban residents` response to the policy of energy-saving and emission-abating and its determinants [J]. Journal of Huazhong Normal University (Natural Sciences), 2012,46(3):358-362.

[2 ] JIN shihua, ZHAO guannan. Farmers ' maintenance to the achievements of SLCP and analysis of its influence factors[J]. Ecological Economy, 2011, (02):16-19.

[3] KE Shuifa, ZHAO Tiezhen. Empirical analysis on factors influencing on peasant households` willingness of participation in conversion of cultivated land to forest land program[J]. China Land Science,2008,22(7):27-33.

[4] LU Guiqiao, LU Shaobo, GU Jiancai. Investigation and analysis on satisfaction of farmers to the project of returning grain plots to forestry[J]. Hebei Journal of Forestry and Orchard Research, 2005,20(1):14-17.

[5] ZHAO Aitao, LIU Tianming. Farmers` Awareness and reaction to the policy of returning farm land and grazing land to grasses in ningxia. Chinese Journal of Grassland,2008,30(1):112-116.

[6] WU Chengliang, SU Yinquan, WANG Liqun etc. Research on grain for green project from economic perspectives[J]. Journal of Northwest A\&F University(Social Science Edition) ,2007,(06):55-58. 